\title{
Experiencing stigma: Nepalese perspectives
}

\author{
Adhikari SR', Pradhan $\mathrm{SN}^{2}$, Sharma $\mathrm{SC}^{2}$ \\ ${ }^{1}$ Lecturer, ${ }^{2}$ Assistant Professors, Department of Psychiatry, KMCTH, Sinamangal, Nepal
}

\begin{abstract}
Background: Experiencing stigma by patients with mental illness in their day to day lives has substantial importance in treatment, compliance and quality of life. There is dearth of information and researches in experiences/ perceptions and coping of stigma in Nepal.

Aims: The objective of this study was to find out experiences/ perceptions and coping of stigma and stigmatizations among patients with mental illness.

Materials and methods: This is a retrospective, cross sectional study of patients admitted in psychiatry ward. Patients were assessed using self-report questionnaire which focused on beliefs about discrimination against mental illness, rejection experiences, and ways of coping with stigma. Patient's socio demographic profiles were also assessed.

Results: Fifty three patients completed questionnaire concerning various constructs of stigma. There were 29 male patients and 24 female patients. Majority $(\mathrm{N}=45 ; 84.9 \%)$ were of Hindu religion but there were mixed numbers regarding caste. Most of the patients were aware of the stigma associated with mental illness. There were experiences of rejection by family members and colleagues $(\mathrm{N}=23 ; 43.4 \%)$ and health care professional $(\mathrm{N}=16 ; 30.2 \%)$. There were strong perceptions of stigmatization felt by patients in different social circumstances. Though maintaining secrecy and avoidance/withdrawal of stigma provoking scenario were not experienced much, there was a strong sense of advocacy whenever there was any negative view of mental illness. Some of the questionnaire items in "perception", "rejection" and "coping" showed statistical significance $(\mathrm{p}=0.001)$.

Conclusion: People with mental illness experience stigma during their course of illness and treatment and it is an important determinant for the relapse of symptoms and non-compliance to treatment. Despite experiencing stigma, patients were generally treated fairly by other people. Patients develop various mechanisms to cope with stigma, mostly secrecy and avoidance. Advocacy and anti-stigma campaign along with positive attitudes of health professionals play important role in decreasing stigmatizing experiences in patients.
\end{abstract}

Key Words: Stigma, stigmatization, mental illness, coping, perception.

Q tigma marks someone different from others, leading $\checkmark$ to devaluation of that person. Goffman ${ }^{1}$ defines stigma as "an attribute that is deeply discrediting", where a person is diminished "from a whole and usual person to a tainted and discounted one". Stigma has become a marker for adverse experiences. There are numerous personal accounts of psychiatric illness, where shame overrides even the most extreme of symptoms ${ }^{2}$. In two identical UK public opinion surveys, little change was recorded over ten years, with over $80 \%$ endorsing the statement that "most people are embarrassed by mentally ill people", and about 30\% agreeing "I am embarrassed by mentally ill persons"3. Stigma obstructs social integration and recovery as a consequence of certain psychosocial processes leading to stigmatization. These psychosocial constructs include labeling, stereotyping, status loss and discrimination in context of power imbalance ${ }^{4}$.

\begin{tabular}{|l|}
\hline Box 1 The experience of STIGMA ${ }^{2}$ \\
\hline Shame \\
Blame \\
Secrecy \\
The "black sheep of the family" role \\
Isolation \\
Social exclusion \\
Stereotypes \\
Discrimination \\
\hline
\end{tabular}

Prejudice and discrimination related to mental illness lead to poor treatment compliance, increased social

Correspondence

Dr. Shailendra Raj Adhikari

Department of Psychiatry

Kathmandu Medical College Teaching Hospital (KMCTH)

Sinamangal, Kathmandu, Nepal

E-mail: sra372@gmail.com 
isolation, difficulty in finding housing, education and employment and increased probability of alcohol and drug abuse.

Stigma in mental illness is of three types (a) public stigma, (b) self stigma, (c) courtesy stigma (stigma endured by family and care givers). Apart from public stigma and courtesy stigma, self stigma is the most detrimental one. It leads to worsen individuals' recovery ${ }^{5}$ and prevent $\mathrm{him} /$ her from seeking professional assistance ${ }^{6}$.

As described in figure 1, negative public opinion about mental illness leading to self stigmatization becomes a stumbling block for the recovery in patients with mental illness. This starts the vicious cycle of stigmatization, leading to struggle to recovery/exaggeration of illness which further leads to isolation from the mainstream culture. These lead to increased burden on patients and their families ${ }^{8}$.

Experiences and perceptions of stigma among patients are important to know so that patients can be given adequate counseling and direction to prevent vicious cycles described before. Though stigma related researches and articles are coming in voluminous amount, most of them are attitude surveys of community and patients' family members and care givers. Very few studies have been done regarding experiences and a concept of stigma among sufferers of mental illness. This study was done in this context and it is the first study of its kind in Nepal, which tries to find out experiences/perceptions and coping of stigma.

\section{Materials and methods}

This is a retrospective cross sectional study done at Kathmandu Medical College Teaching Hospital (KMCTH). Department of Psychiatry at KMCTH has in-patients, outpatient services along with clinical psychology facility. It has three psychiatrists, one clinical psychologist, one qualified medical doctor and one psychiatry nurse along with other nursing and nontechnical staffs. The department has 12 inpatient beds along with psychotherapy room and recreational facility. The current study was done at the in-patient unit of the department. Patients who were admitted from January 2007 to June 2007 in the hospital were considered for study. All the patients who were admitted in psychiatry ward were assessed.

Following inclusion criteria were used:

1. Patients giving consent for the study

2. Patients aged 18-60 years

3. Based on assessment by the researchers, the patient was in remission or not severely ill
After patients' assessment, a day or two before discharge, they were given self-report questionnaire assessing beliefs about discrimination against individuals with mental illness, rejection experiences and ways of coping with stigma.

During six months of periods, 114 patients were admitted in the psychiatry ward. Eighty seven patients were found to be fit to answer the questionnaire. Twenty two patients refused to give consent. Sixty five patients were recruited. The questionnaire was modified and derived from versions previously used in other studies 9,10,11. English to Nepali and Nepali to English translation was done with the help of language faculties of university. Wording and sentences were made easier to understand. Participants rated the section on perception of stigmatization and experience of rejection using five point response scales ["Strongly Disagree", "Slightly Disagree", "Can't say/Don't know", and "Slightly Agree", "Strongly Agree"]. Items assessing rejection experiences and coping strategies used three point response scales ["Yes", "Don't Know", "No"]. Participants were advised to answer "Don't Know" if they had not encountered the relevant situation, to avoid overestimating negative responses.

All socio demographic and questionnaire data were recorded on pre-designed proforma. The collected data were checked and coded manually and entered in the computer. Statistical analysis was performed with SPSS program (version 12). Data interpretation was done along with mean, standard deviation. Chi-Square Test was used to assess the statistical significance of the associations between the variables.

\section{Results}

There were 53 patients, 29 of them were females and 24 were males. Forty five $(84.9 \%)$ patients were of Hindu whereas rest followed other religions. Brahmin $(\mathrm{N}=11 ; 20.8 \%)$, Chettri $(\mathrm{N}=17 ; 32.1 \%)$ and Newar $(\mathrm{N}=13 ; 24.5 \%)$ were the predominant casts. Most of the patients were either students $(\mathrm{N}=19 ; 35.8 \%)$ or worked in agriculture sector $(\mathrm{N}=11 ; 20.8 \%)$. Majority of patients were secondary passed $(\mathrm{N}=21 ; 39.6 \%)$ or certificate passed $(\mathrm{N}=14 ; 26.4 \%)$ (Table 1$)$.

Mean age of patients were 26.7 years and 41 patients gave no evidence of mental illness in the family (Table2). Twenty five patients had been ill for less than six months whereas five had been ill for six months to one year. Twenty three patients had duration of illness for more than one year (Table 2).

Majority of patients strongly perceived stigmatization against mental illness as shown in Table 3. Stigma perception items where patients "Slightly Agree" and 
"Strongly Agree" were more than 50 percentage of response were SP1 (Untrustworthy), SP2 (Not Marry), SP4 (Opinion taken less seriously), SP5 (Looked down by people), SP6 ((Less intelligent), SP9 (Not accepted as close friend) and SP10 (Treatment as a personal failure). This shows strong perceptual responses considering stigma. As shown in Table 5, few patients experienced "rejection" as signs of stigma - "Slightly Agree" and "Strongly Agree" having more than 50 percentage of responses in RE2 (Avoided by other people), RE9 (Asked to resign due to mental illness), RE10 (Neglected by health professional).

Patients in this study gave strong opinion regarding advocacy and confrontation of stigma in social circumstances - Advocacy 1 (Correcting friends holding negative view; Yes[N=38(75.5\%)]), Advocacy3 (Complain if treated unfairly; Yes[N=38(71.7\%)]), Advocacy4 (Participate in social activities; Yes[N=42(79.2\%)]), Advocacy5 (Refuse to resign if asked for; Yes[N=34(64.2\%)]) as shown in Table
7. There were few "Yes" responses regarding other items of coping against mental illness - "Secrecy" and "Avoidance" and "Withdrawal". Most of the responses were either "No" or "Don't know/can't say" in these items as given in Table 7 .

Five items of questionnaire for "stigma perception" [SP2, SP4, SP6, SP9, SP10] had shown statistical significance as given in Table 4. Only two items of "rejection experience" [RE1, RE2] showed statistical significance, as given in Table 6. As described in Table 8 , there were many items of "coping" showing statistical significance. Three items of "secrecy" [secrecy2, secrecy3, secrecy 6] showed significance out of seven items. Out of seven items of "avoidance", only two showed statistical significance [avoidance 5, avoidance 6]. Regarding "advocacy", out of five items, four items showed statistical significance [advocacy 1, advocacy 3 , advocacy 4, advocacy 5]. This implies strong sense of advocacy in patients whenever they are facing stigma and discrimination.

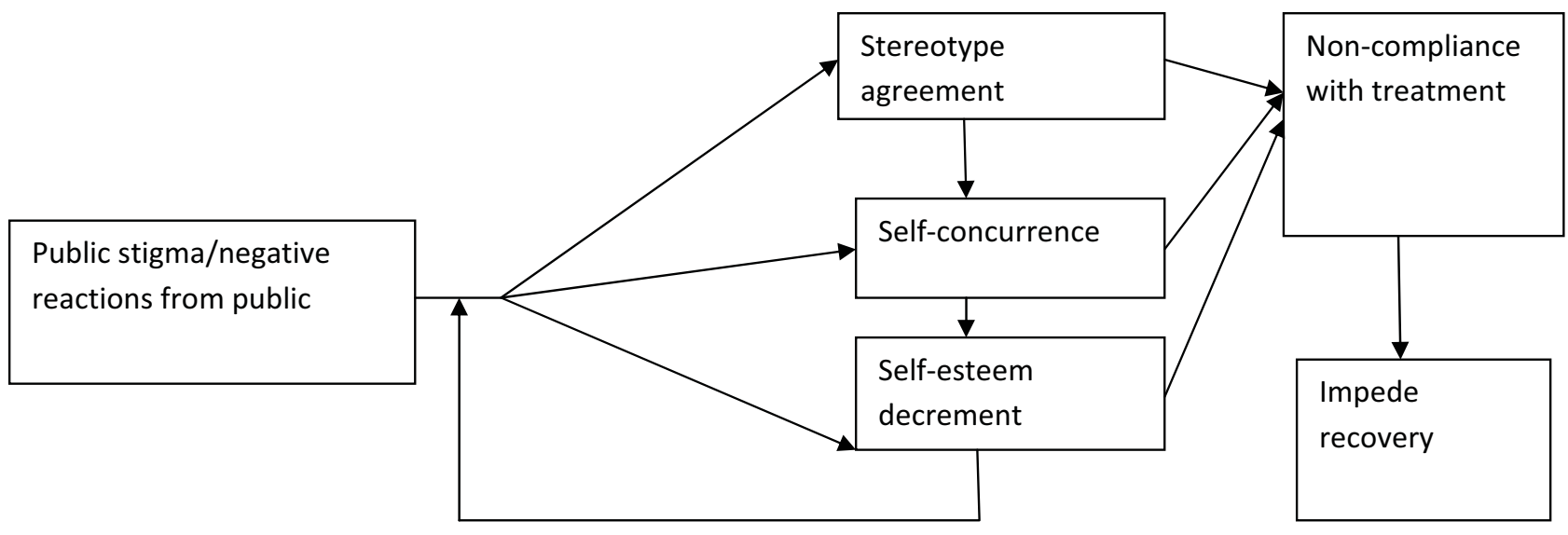

Fig 1: Simplified process of self-stigmatization on recovery ${ }^{7}$ 
Table 1: Socio-demographic Characteristics of Patients $(\mathrm{N}=53)$

\begin{tabular}{|c|c|c|}
\hline GENDER & $\begin{array}{l}\text { Male } \\
\text { Female }\end{array}$ & $\begin{array}{r}29(54.7 \%) \\
24(45.3 \%)\end{array}$ \\
\hline RELIGION & $\begin{array}{l}\text { Hindu } \\
\text { Buddhist } \\
\text { Muslim } \\
\text { Christian }\end{array}$ & $\begin{array}{r}45(84.9 \%) \\
4(7.5 \%) \\
1(1.9 \%) \\
3(5.7 \%)\end{array}$ \\
\hline CASTE & $\begin{array}{l}\text { Brahmin } \\
\text { Chettri } \\
\text { Newar } \\
\text { Gurung } \\
\text { Rai } \\
\text { Magar } \\
\text { Tamang } \\
\text { Others }\end{array}$ & $\begin{array}{r}11(20.8 \%) \\
17(32.1 \%) \\
13(24.5 \%) \\
1(1.9 \%) \\
2(3.8 \%) \\
1(1.9 \%) \\
3(5.7 \%) \\
5(9.4 \%)\end{array}$ \\
\hline FAMILY TYPE & $\begin{array}{l}\text { Joint } \\
\text { Nuclear } \\
\text { Others }\end{array}$ & $\begin{array}{r}20(37.7 \%) \\
29(54.7 \%) \\
4(7.5 \%)\end{array}$ \\
\hline OCCUPATION & $\begin{array}{l}\text { Service } \\
\text { Agriculture } \\
\text { Business } \\
\text { Unemployed } \\
\text { Labor } \\
\text { Student } \\
\text { Others } \\
\end{array}$ & $\begin{array}{r}6(11.3 \%) \\
11(20.8 \%) \\
5(9.4 \%) \\
5(9.4 \%) \\
1(1.9 \%) \\
19(35.8 \%) \\
6(11.3 \%) \\
\end{array}$ \\
\hline EDUCATION & $\begin{array}{l}\text { Illiterate } \\
\text { Primary } \\
\text { Lower Secondary } \\
\text { Secondary } \\
\text { Certificate } \\
\text { Bachelor } \\
\text { Others }\end{array}$ & $\begin{array}{r}3(5.7 \%) \\
6(11.3 \%) \\
6(11.3 \%) \\
21(39.6 \%) \\
14(26.4 \%) \\
2(3.8 \%) \\
1(1.9 \%)\end{array}$ \\
\hline
\end{tabular}

Table 2: Socio-demographic Characteristics of Patients (Contd.)

\begin{tabular}{|c|c|c|c|c|}
\hline & Mean & Minimum & Maximum & Standard Deviation \\
\hline AGE (YEARS) & 26.7 & 12 & 60 & 10.05 \\
\hline $\begin{array}{l}\text { FAMILY INCOME } \\
\text { (RUPEES) }\end{array}$ & 8443 & 3000 & 20000 & 3155.67 \\
\hline FAMILY MEMBERS & 5.55 & 2 & 16 & 2.52 \\
\hline $\begin{array}{l}\text { DURATION OF } \\
\text { ILLNESS }\end{array}$ & \multicolumn{4}{|c|}{$\begin{array}{c}\text { Number (\%) } \\
25(47.2 \%) \\
5(9.4 \%) \\
23(43.4 \%) \\
100(\mathbf{1 0 0 \%})\end{array}$} \\
\hline $\begin{array}{l}\text { FAMILY HISTORY OF } \\
\text { MENTAL ILLNESS }\end{array}$ & \multicolumn{4}{|c|}{$\begin{array}{l}\mathrm{N}=12(22.6 \%) \\
\mathrm{N}=41(77.4 \%)\end{array}$} \\
\hline
\end{tabular}


Table 3: Questionnaire of "PERCEPTION" of Stigmatization

\begin{tabular}{|r|r|r|r|r|r|}
\hline \multicolumn{1}{|l}{ ITEMS } & \multicolumn{1}{|c|}{$\begin{array}{c}\text { Strongly } \\
\text { Disagree }\end{array}$} & $\begin{array}{c}\text { Slightly } \\
\text { Disagree }\end{array}$ & $\begin{array}{c}\text { Can't Say/ } \\
\text { Don't Know }\end{array}$ & $\begin{array}{c}\text { Slightly } \\
\text { Agree }\end{array}$ & $\begin{array}{c}\text { Strongly } \\
\text { Agree }\end{array}$ \\
\hline STIGMA PERCEPTION ( SP ) & & & & & \\
SP1 & $6(11.3 \%)$ & $6(11.3 \%)$ & $12(22.6 \%)$ & $19(35.8 \%)$ & $10(18.9 \%)$ \\
SP2 & $3(5.7 \%)$ & $5(9.4 \%)$ & $16(30.2 \%)$ & $9(17 \%)$ & $20(37.7 \%)$ \\
SP3 & $4(7.5 \%)$ & $7(13.2 \%)$ & $12(22.6 \%)$ & $17(32.1 \%)$ & $13(24.5 \%)$ \\
SP4 & $7(13.2 \%)$ & $3(5.7 \%)$ & $12(22.6 \%)$ & $23(43.4 \%)$ & $8(15.1 \%)$ \\
SP5 & $4(7.5 \%)$ & $6(11.3 \%)$ & $10(18.9 \%)$ & $15(28.3 \%)$ & $18(34 \%)$ \\
SP6 & $4(7.5 \%)$ & $6(11.3 \%)$ & $10(18.9 \%)$ & $20(37.7 \%)$ & $13(24.5 \%)$ \\
SP7 & $8(15.1 \%)$ & $8(15.1 \%)$ & $13(24.5 \%)$ & $16(30.2 \%)$ & $8(15.1 \%)$ \\
SP8 & $12(22.6 \%)$ & $5(9.4 \%)$ & $13(24.5 \%)$ & $10(18.9 \%)$ & $13(24.5 \%)$ \\
SP9 & $4(7.5 \%)$ & $6(11.3 \%)$ & $14(26.4 \%)$ & $21(39.6 \%)$ & $8(15.1 \%)$ \\
SP 10 & $9(17 \%)$ & $4(7.5 \%)$ & $12(22.6 \%)$ & $22(41.5 \%)$ & $6(11.3 \%)$ \\
\hline
\end{tabular}

Table 4: Statistical significance of questionnaire of "PERCEPTION" of Stigmatization

\begin{tabular}{|c|c|c|}
\hline ITEMS & $\begin{array}{c}\mathbf{9 5 \%} \text { Confidence Interval of } \\
\text { difference (C.I.) [Lower-Upper] }\end{array}$ & $\begin{array}{c}\text { Statistical significance } \\
\text { [ "p" } \mathbf{p a l u e ]}\end{array}$ \\
\hline STIGMA PERCEPTION ( SP) & $3.05-3.74$ & 0.028 \\
SP1 & $3.38-4.06$ & 0.001 \\
SP2 & $3.19-3.86$ & 0.042 \\
SP3 & $3.08-3.75$ & 0.001 \\
SP4 & $3.35-4.05$ & 0.011 \\
SP5 & $3.27-3.93$ & 0.005 \\
SP6 & $2.79-3.51$ & 0.267 \\
SP7 & $2.72-3.54$ & 0.371 \\
SP8 & $3.13-3.74$ & 0.001 \\
SP9 & $2.88-3.58$ & 0.001 \\
\hline
\end{tabular}

Table 5: Questionnaire of "EXPERIENCES OF REJECTION" due to stigma

\begin{tabular}{|r|r|r|r|r|r|}
\hline \multicolumn{1}{|r|}{ ITEMS } & \multicolumn{1}{c|}{$\begin{array}{c}\text { Strongly } \\
\text { Disagree }\end{array}$} & $\begin{array}{c}\text { Slightly } \\
\text { Disagree }\end{array}$ & $\begin{array}{c}\text { Can't Say/ } \\
\text { Don't Know }\end{array}$ & Slightly Agree & Strongly Agree \\
\hline REJECTION & & & & & \\
EXPERIENCE (RE) & & & & & \\
RE1 & $3(5.7 \%)$ & $7(13.2 \%)$ & $21(39.6 \%)$ & $14(26.4 \%)$ & $8(15.1 \%)$ \\
RE2 & $2(3.8 \%)$ & $9(17 \%)$ & $12(22.6 \%)$ & $7(13.2 \%)$ & $23(43.4 \%)$ \\
RE3 & $7(13.2 \%)$ & $11(20.8 \%)$ & $10(18.9 \%)$ & $12(22.6 \%)$ & $13(24.5 \%)$ \\
RE4 & $11(20.8 \%)$ & $7(13.2 \%)$ & $16(30.2 \%)$ & $14(26.4 \%)$ & $5(9.4 \%)$ \\
RE5 & $13(24.5 \%)$ & $8(15.1 \%)$ & $17(32.1 \%)$ & $5(9.4 \%)$ & $10(18.9 \%)$ \\
RE6 & $13(24.5 \%)$ & $7(13.2 \%)$ & $14(26.4 \%)$ & $11(20.8 \%)$ & $8(15.1 \%)$ \\
RE7 & $11(20.8 \%)$ & $2(3.8 \%)$ & $13(24.5 \%)$ & $14(26.4 \%)$ & $13(24.5 \%)$ \\
RE8 & $9(17 \%)$ & $6(11.3 \%)$ & $11(20.8 \%)$ & $12(22.6 \%)$ & $15(28.3 \%)$ \\
RE9 & $4(7.5)$ & $5(9.4 \%)$ & $14(26.4 \%)$ & $16(30.2 \%)$ & $14(26.4 \%)$ \\
RE10 & $12(22.6 \%)$ & $4(7.5 \%)$ & $8(15.1 \%)$ & $13(24.5 \%)$ & $16(30.2 \%)$ \\
\hline
\end{tabular}


Table 6: Statistical significance of questionnaire of "EXPERIENCES OF REJECTION" due to stigma

\begin{tabular}{|r|c|c|}
\hline \multicolumn{1}{|c|}{ ITEMS } & $\begin{array}{c}\text { 95\% Confidence Interval of difference C.I.) } \\
\text { [Lower-Upper] }\end{array}$ & $\begin{array}{c}\text { Statistical significance } \\
\text { [ "p" } \mathbf{p} \text { value] }\end{array}$ \\
\hline REJECTION EXPERIENCE (RE) & & 0.001 \\
RE1 & $3.03-3.62$ & 0.001 \\
RE2 & $3.4-4.11$ & 0.736 \\
RE3 & $2.86-3.63$ & 0.09 \\
RE4 & $2.55-3.26$ & 0.09 \\
RE5 & $2.44-3.22$ & 0.476 \\
RE6 & $2.50-3.27$ & 0.057 \\
RE7 & $2.91-3.70$ & 0.371 \\
RE8 & $2.94-3.74$ & 0.017 \\
RE9 & $3.25-3.92$ & 0.084 \\
\hline
\end{tabular}

Table 7: Questionnaire of “COPING” strategies against stigma

\begin{tabular}{|c|c|c|c|c|}
\hline \multicolumn{2}{|c|}{ ITEMS } & YES & CAN'T SAY/DON'T KNOW & NO \\
\hline \multirow[t]{7}{*}{ SECRECY } & Secrecyl & $13(24.5 \%)$ & $13(24.5 \%)$ & $27(50.9)$ \\
\hline & Secrecy 2 & $14(26.4 \%)$ & $9(17 \%)$ & $30(56.6 \%)$ \\
\hline & Secrecy 3 & $12(22.6 \%)$ & $10(18.9 \%)$ & $31(58.5 \%)$ \\
\hline & Secrecy4 & $23(43.4 \%)$ & $14(26.4 \%)$ & $16(30.2 \%)$ \\
\hline & Secrecy 5 & $21(39.6 \%)$ & $9(17 \%)$ & $23(43.4 \%)$ \\
\hline & Secrecy6 & $11(20.8 \%)$ & $5(9.4 \%)$ & $37(69.8 \%)$ \\
\hline & Secrecy 7 & $25(47.2)$ & $18(34 \%)$ & $10(18.9 \%)$ \\
\hline \multirow[t]{7}{*}{ AVOIDANCE } & Avoidance1 & $23(43.4 \%)$ & $15(28.3 \%)$ & $15(28.3 \%)$ \\
\hline & Avoidance2 & $20(37.7 \%)$ & $12(22.6 \%)$ & $21(39.6 \%)$ \\
\hline & Avoidance 3 & $16(30.2 \%)$ & $11(20.8 \%)$ & $26(49.1 \%)$ \\
\hline & Avoidance4 & $18(34 \%)$ & $10(18.9 \%)$ & $25(47.2 \%)$ \\
\hline & Avoidance5 & $19(35.8 \%)$ & $7(13.2 \%)$ & $27(50.9 \%)$ \\
\hline & Avoidance6 & $13(24.5 \%)$ & $10(18.9 \%)$ & $30(56.6 \%)$ \\
\hline & Avoidance 7 & $24(45.3 \%)$ & $8(15.1 \%)$ & $21(39.6 \%)$ \\
\hline \multirow[t]{5}{*}{ ADVOCACY } & Advocacy 1 & $40(75.5 \%)$ & $6(11.3 \%)$ & $7(13.2 \%)$ \\
\hline & Advocacy2 & $26(49.1 \%)$ & $13(24.5 \%)$ & $14(26.4 \%)$ \\
\hline & Advocacy3 & $38(71.7 \%)$ & $12(22.6 \%)$ & $3(5.7 \%)$ \\
\hline & Advocacy4 & $42(79.2 \%)$ & $8(15.1 \%)$ & $3(5.7 \%)$ \\
\hline & Advocacy5 & $34(64.2 \%)$ & $14(26.4 \%)$ & $5(9.4 \%)$ \\
\hline
\end{tabular}


Table 8: Statistical significance of questionnaire of "COPING" strategies against stigma

\begin{tabular}{|c|c|c|c|}
\hline \multicolumn{2}{|l|}{ ITEMS } & $\begin{array}{l}\text { 95\% Confidence Interval of difference (C.I.) } \\
\text { [Lower-Upper] }\end{array}$ & $\begin{array}{c}\text { Statistical significance } \\
\text { [ "p" value] }\end{array}$ \\
\hline SECRECY & $\begin{array}{l}\text { Secrecy1 } \\
\text { Secrecy2 } \\
\text { Secrecy3 } \\
\text { Secrecy4 } \\
\text { Secrecy5 } \\
\text { Secrecy6 } \\
\text { Secrecy7 }\end{array}$ & $\begin{array}{l}2.03-2.49 \\
2.06-2.54 \\
2.13-2.59 \\
1.63-2.10 \\
1.78-2.29 \\
2.26-2.72 \\
1.51-1.93\end{array}$ & $\begin{array}{l}0.025 \\
0.001 \\
0.001 \\
0.282 \\
0.039 \\
0.001 \\
0.041\end{array}$ \\
\hline AVOIDANCE & $\begin{array}{l}\text { Avoidance1 } \\
\text { Avoidance2 } \\
\text { Avoidance3 } \\
\text { Avoidance4 } \\
\text { Avoidance5 } \\
\text { Avoidance6 } \\
\text { Avoidance7 }\end{array}$ & $\begin{array}{l}1.62-2.08 \\
1.77-2.26 \\
1.95-2.43 \\
1.88-2.38 \\
1.90-2.41 \\
2.09-2.55 \\
1.69-2.20 \\
\end{array}$ & $\begin{array}{l}0.299 \\
0.252 \\
0.037 \\
0.041 \\
0.003 \\
0.001 \\
0.017 \\
\end{array}$ \\
\hline ADVOCACY & $\begin{array}{l}\text { Advocacy1 } \\
\text { Advocacy2 } \\
\text { Advocacy3 } \\
\text { Advocacy4 } \\
\text { Advocacy5 }\end{array}$ & $\begin{array}{l}1.18-1.57 \\
1.54-2.01 \\
1.18-1.50 \\
1.11-1.42 \\
1.27-1.64\end{array}$ & $\begin{array}{l}0.001 \\
0.052 \\
0.001 \\
0.001 \\
0.001\end{array}$ \\
\hline
\end{tabular}

\section{Discussion}

This study has important implications in relation to stigma and its relation to mental illness in Nepali context since this is the first of its type in Nepal. Our patients strongly perceived stigma and feel stigmatized in very social context in which they are residing and they have to cope these situations which has been also substantiated by other studies ${ }^{11,12,13,14}$. This study gives some glimpses about how difficult it is to live with mental illness and to face day to day activities. High agreement in items of sigma perception (marrying someone mental illness, opinion taken less seriously, looked down upon, less intelligent, not accepted as close friends, treatment as signs of failure in Table 3 ) show that patients could be discriminated in many ways.

A study conducted in the USA among patients with schizophrenia receiving out-patient treatment found that stigma experiences were common, but actual discrimination were less frequent ${ }^{13}$. Half of the samples replied "sometimes", "often" or "very often" on items treated less competent, turned down on job, difficulty in renting apartment, denial in educational opportunities and exclusion from voluntary activities. This response indicates that they were generally treated fairly by others. In one UK study, 56\% experienced discriminations within family, 51\% from friends, $47 \%$ in the workforce and $44 \%$ from general practitioners 15. Another study was done in the USA about racial differences in stigmatizing attitudes toward individuals with mental illness ${ }^{16}$ which highlighted the complexity of the stigma process and emphasized the need to consider racial differences in developing interventions targeted to improve public attitudes.

The stigma associated with mental illness also harms self-esteem as shown in this study ("Rejection" items in Table 5). An important consequence of reducing stigma would be to improve the self-esteem of people who have mental illness ${ }^{17}$. Stereotype of danger and desire for social distance persist despite much advancement in psychiatry etiology and management ${ }^{18}$. Studies conducted in China ${ }^{19}$, Israel ${ }^{20}$ and Fiji ${ }^{21}$ gives similar finding that has been deducted in this study.

This study has limitations: (a) it is a non-random sampling. (b) Study was conducted in hospital in-patient set up and it's difficult to generalize these findings. (c) Being self-report questionnaire, it did not facilitate emotional expressions and stigma experiences as could have been done in an interview.

\section{Conclusion}

\begin{tabular}{|rl|}
\hline Box 2: & Ways to reduce the stigma of mental illness ${ }^{22}$ \\
\hline i. & Examine our own attitudes \\
ii. & Update our knowledge of mental illness \\
iii. & Listen to what our patients say about mental \\
& illness and its consequences \\
iv. & Watch out for stigmatizing language \\
v. & Advocate for those with mental illness \\
vi. & Add political activism to our daily work \\
vii. & Challenge stigma in the media
\end{tabular}


To improve the life quality of people with mental disorders, decrease the burden of mental illness on families, realize mental health reforms, and generate new knowledge that can be used to reduce psychiatric disability, stigma must be beaten ${ }^{23}$. Every mental health professional has a very critical role to play to reduce stigma on patients. Due to nature of stigma, it is unlikely that patients will tell "I am stigmatized or experiencing discriminations due to mental illness". Mental health professionals (importantly psychiatrists) should ask about nature of adverse experiences, discrimination, self image, extent of social networks and stereotyping behaviors/languages and incorporate these issues into the treatment plan. Inquiring patients about "stigma" and "prejudice" is as important as asking patients about "suicidal ideation" and "death wish". Strong anti-stigma campaign at the national level will have significant impact on reducing stigma against people with mental illness.

\section{References}

1. Goffman E. Stigma: Notes on the management of spoiled identity. New York: Prentice Hall. Inc; 1963.

2. Byrne P. Stigma of mental illness and ways of diminishing it. Advances in Psychiatric Treatment 2000;6:65-72.

3. Huxley P. Location and stigma: a survey of community attitudes to mental illness: enlightenment and stigma. Journal of Mental Health UK. 1993;2:73-80.

4. Link BG, Phelan JC. Conceptualizing stigma. Annual Rev of Sociology 2001;27:363-85.

5. Ritsher JB, Phelan JC. Internalized stigma predicts erosion of morale among psychiatric outpatients. Psychiatric Research 2004;129(3):257-65.

6. Meltzer H, Bebbington P, Brugha T, Farrell $\mathrm{M}$, Jenkins R, Lewis G. The reluctance to seek treatment for neurotic disorders. International Review of Psychiatry 2003;15:123-8.

7. Fung Kelvin MT, Sang T, Hector WH, Corrigan PW, Lam CS, Cheng Wai-Ming. Measuring self stigma of mental illness in China and its implications for recovery. International Journal of Social Psychiatry 2007;53(5):408-18.

8. Sartorius N. One of the last obstacles to better mental health care: the stigma of mental illness. In: Guimon J, Fisher W, Sartorius N (eds). The Images of Madness. Kerger: Basel; 1999. P. 96104.

9. Link BG, Mirotznik J, Cullen FT. The effectiveness of stigma coping orientations: can negative consequences of mental illness labeling be avoided? Journal of Health and Social Behavior 1991;32:302-20.
10. Link BG, Struening EL, Rahav M. On stigma and its consequences: evidence from a longitudinal study of men with dual diagnoses of mental illness and substance abuse. Journal of Health and Social Behavior 1997;38:177-90.

11. Wahl OF. Mental health consumers experience of stigma. Schizophrenia Bulletin 1999;38:46778.

12. Camp DL, Finlay WML, Lyons E. Is low selfesteem an inevitable consequence of stigma? An example from women with chronic mental health problems. Social Science and Medicine 2002;55:823-34.

13. Dickerson FB, Sommervillie J, Origoni AE. Experiences of stigma among outpatients with schizophrenia. Schizophrenia Bulletin 2002;28:143-55.

14. Schulze B, Angermeyer MC. Subjective experiences of stigma. A focus group study of schizophrenic patients, their relatives and mental health professionals. Social Science and Medicine 2003;56:299-312.

15. MentalHealthFoundation.Pullyourselftogether: A survey of the stigma and discrimination faced by people who experience mental distress. London: Mental Health Foundation; 2000.

16. Anglin DM, Link BG, Phelan JC. Racial differences in stigmatizing attitudes toward people with mental illness. Psychiatric Serv. 2006June;57(6):857-62.

17. LinkBG, StrueningEL, Neese-ToddS,Asmussen S, Phelan JC. Stigma as a barrier to recovery: The consequences of stigma for the self-esteem of people with mental illness. Psychiatric Serv. 2001 December;52(12):1621-6.

18. Link BG, Phelan JC, Bresnahan M, Stueve A, Pescosolido BA. Public conceptions of mental illness: labels, causes, dangerousness, and social distance. Am J Public Health 1999;89(9):132833.

19. Chung KF, Wong MC. Experiences of stigma among Chinese mental health patients in Hong Kong. Psychiatric Bulletin 2004;28:451-4.

20. TalA. Mental illness stigma in the Israeli context: Deliberations and suggestions. International Journal of Social Psychiatry 2007;53(6):54763.

21. Aghanwa HS. Attitude toward and knowledge about mental illness in Fiji Islands. International Journal of Social Psychiatry 2004;50(4):36175.

22. Bolton J. Reducing the stigma of mental illness. Student BMJ 2003(April);11:104-5.

23. Stuart H. Why stigma matters and why it should be beaten. World Psychiatry 2005(September);4(suppl.1):6-7. 